J. Clin. Chem. Clin. Biochem.

Vol. 19, 1981, pp. 21-23

\title{
Some Studies on the Effects of Ambilhar on Mobilisation and Excretion of Lead
}

\author{
By T.M. N. Al-Khayat and F. T. Abdel Aziz \\ Dept. of Medical Biochemistry. Med. Coll. Mosul University, Mosul, Iraq
}

(Received January 15/July 3, 1980)

Summary: The effects of administration of ambilhar to guinea pigs intoxicated with lead for one and three weeks were investigated. The results showed that administration of ambilhar to guinea pigs dosed with lead acetate resulted in a significant decrease in the liver content of lead with a concomitant increase in urinary and faecal lead excretion.

The rate of lead elimination from the body was found to be dose depedent. The ultra violet studies of ambilhar and its lead soluble complex in vitro supported the possibility that the stimulation of lead excretion results from the formation of a lead-ambilhar complex.

\section{Untersuchungen über die Wirkung von Ambilhar auf die Mobilisierung und Ausscheidung von Blei}

Zusammenfassung: Die Wirkungen der Verabreichung von Ambilhar an Meerschweinchen, die für eine Woche und drei Wochen mit Bleiacetat vergiftet wurden, wurden untersucht. Ambilhar bewirkte bei den bleivergifteten Tieren ein signifikante Minderung des Bleigehalts der Leber mit einem gleichzeitigen Anstieg der Bleiausscheidung in Faeces und Urin.

Das Ausmaß der Bleielimination war dosisabhängig. Ultraviolett-spektroskopische Untersuchungen von Ambilhar und seinem löslichen Bleikomplex in vitro unterstützen die Möglichkeit der Bindung von Blei an Ambilhar, wodurch die Bleiausscheidung gefördert wird.

\section{Introduction}

Earlier studies on the antibilharzial drug ambilhar revealed its metal ligating ability. Salah et al. (1) and Abdel-Aziz et al. (2) demonstrated the excretion of iron in the urine of man and animals after administration of ambilhar.

In 1978 Al-Khayat et al. (3) reported similar effects on body calcium and magnesium. The possibility that this drug could form a similar complex with lead was therefore investigated.

The present work examines the possibility that ambilhar forms a soluble lead complex in vivo as well as in vitro; and the ability of this drug to stimulate lead excretion is investigated.

\section{Materials and Methods}

In vivo investigations

60 Male adult guinea pigs, average body weight $450-500 \mathrm{~g}$, were used in this study. They were fed with ordinary fresh vegetables collected for animals in the college animal house. They were divided into 6 equal groups.

The animals of groups 1,2 and 3 were given lead acetate in a daily dose level of $50 \mathrm{mg}$ per animal intraperitoneally for 7 con- secutive days. After this period the animals of groups 2 and 3 were treated with ambilhar at a daily dose level of 5 and $50 \mathrm{mg}$ per animal as an aqueous suspension administered by a stomach tube for 7 consecutive days, while animals of group 1 were kept as control. The urine and faeces of each animal were collected daily in a metabolic cage. After the last day of ambilhar administration, all animals of groups 1,2 and 3 were sacrificed.

The animals of groups 4,5 and 6 were given lead acetate intraperitoneally at the same dose level ( $50 \mathrm{mg}$ per animal) daily for 21 consecutive days. Then animals of groups 5 and 6 were treated with ambilhar for 7 consecutive days at a daily dose level of 5 and $50 \mathrm{mg}$ per animal, while animals of group 4 were kept as control. The urine and faeces of each animal were collected daily in a metabolic cage. After the last day of ambilhar administration, all animals of groups 4,5 and 6 were sacrificed.

Estimation of lead content of liver, urine and faeces

One gram samples of fresh liver from each animal were exactly weighed. One $\mathrm{ml}$ of urine and one gram of faeces from mixed urine and mixed faecal matter of each group were used for analysis. All samples were dried at $105^{\circ} \mathrm{C}$ and then ashed in a muffle furnace at $600^{\circ} \mathrm{C}$ for 5 hours. The ash was used for the determination of lead after dissolving in $2 \mathrm{ml}$ of $20 \mathrm{~g} / \mathrm{l}$ acetic acid. Estimation of the lead content of each sample was performed using a Perkin-Elmer 503 atomic absorption spectrophotometer (4).

A working stock standard solution of lead acetate was prepared by dissolving one gram pure powdered lead acetate (BDH) in one liter of $20 \mathrm{~g} / \mathrm{l}$ acetic acid. One $\mathrm{ml}$ of this stock solution was diluted to one liter using $20 \mathrm{~g}$ acetic acid and used as a daily working standard for a calibration curve. 


\section{In vitro investigations}

To $500 \mathrm{mg}$ pure lead acetate (BDH) one gram pure ambilhar (Ciba-Geigy Labs) and two grams sodium metabisulphite (BDH) were added. The whole mixture was pulverised in a mortar and transferred to a $500 \mathrm{ml}$ beaker. Distilled water $(25 \mathrm{ml})$ was added to the mixture with gentle warming on a waterbath at $70^{\circ} \mathrm{C}$ for 10 minutes, where a clear colorless solution was obtained with the remaining excess lead acetate on the bottom. It was filtered, concentrated to about $5 \mathrm{ml}$ under reduced pressure and left in a refrigerator; crystalline white needles were obtained which by ignition decomposed leaving a white residue of lead oxide.

A few crystals were dissolved in $5 \mathrm{ml}$ distilled water and its ultra violet spectrum was measured (fig. 1). The crystalline needles were found to contain $69 \%$ lead. The soluble complex formed runs as a single spot on ascending paper chromatography using Whatman No. 1 filter paper with $n$-butanol, acetic acid and water (volumes, $20 \mathrm{ml}+20 \mathrm{ml}+10 \mathrm{ml}$ ) as a solvent system.

\section{Results}

Table 1 shows the effect of ambilhar at two different dose levels on liver lead content and on the urinary and faecal lead excretion. A significant decrease of liver lead content with concomitant increase in urinary and faecal lead output was observed with the two dose levels of ambilhar ( 5 and $50 \mathrm{mg}$ per animal per day). With the higher dose level the drug showed a more significant effect on liver lead depletion, and on urinary and faecal lead excretion. At a dose level of $5 \mathrm{mg}$ of ambilhar, about $80 \%$ of liver lead was depleted, and at a dose level of $50 \mathrm{mg}$ nearly all the metal was eliminated from the liver.

Table 2 shows the effect of ambilhar on the lead content of the liver, urine and faeces after prolonged administration of lead acetate for three weeks. At a lower dose level of ambilhar ( $5 \mathrm{mg}$ per animal per day) for 7 consecutive days, about $50 \%$ of liver lead was removed, while at the higher dose level (50 mg per animal per day) about $84 \%$ of liver lead was eliminated. Also a significant increase in urinary and faecal lead excretion was found.

Tab. 1. Effect of ambilhar administration on the liver content of lead after injection of lead acetate for one week (50 mg per animal per day).

\begin{tabular}{|c|c|c|c|c|}
\hline Group of animals & $\begin{array}{l}\text { Num- } \\
\text { ber } \\
\text { of } \\
\text { ani- } \\
\text { mals }\end{array}$ & $\begin{array}{l}\text { Liver } \\
\text { lead } \\
\text { mg/kg } \\
\text { fr. wt. }\end{array}$ & $\begin{array}{l}\text { Urinary } \\
\text { lead } \\
\mathrm{mg} / \mathrm{l}\end{array}$ & $\begin{array}{l}\text { Faecal } \\
\text { lead } \\
\mathrm{mg} / \mathrm{kg} \\
\text { fr. wt. }\end{array}$ \\
\hline $\begin{array}{l}\text { Group } 1 \\
\text { dosed with lead } \\
\text { only (control) }\end{array}$ & 10 & $\begin{array}{c}5.5 \\
\pm(0.25)\end{array}$ & $\begin{array}{c}0.05 \\
\pm(0.035)\end{array}$ & $\begin{array}{c}0.03 \\
\pm(0.02)\end{array}$ \\
\hline $\begin{array}{l}\text { Group } 2 \\
\text { dosed with } \\
5 \mathrm{mg} \text { ambilhar } \\
\text { after lead }\end{array}$ & 10 & $\begin{array}{c}1.25^{* *} \\
\pm(0.16)\end{array}$ & $\begin{array}{c}0.35^{* *} \\
\pm(0.1)\end{array}$ & $\begin{array}{l}\dot{0.20 * *} \\
\pm(0.11)\end{array}$ \\
\hline $\begin{array}{l}\text { Group } 3 \\
\text { dosed with } \\
50 \mathrm{mg} \text { ambilhar } \\
\text { after lead }\end{array}$ & 10 & $\begin{array}{l}0.15^{* *} \\
\pm(0.12)\end{array}$ & $\begin{array}{r}0.96 * * \\
\pm(0.125)\end{array}$ & $\begin{array}{r}0.55^{* *} \\
\pm(0.155)\end{array}$ \\
\hline
\end{tabular}

\footnotetext{
\pm standard deviation

** significant at $1 \%$ level of probability
}

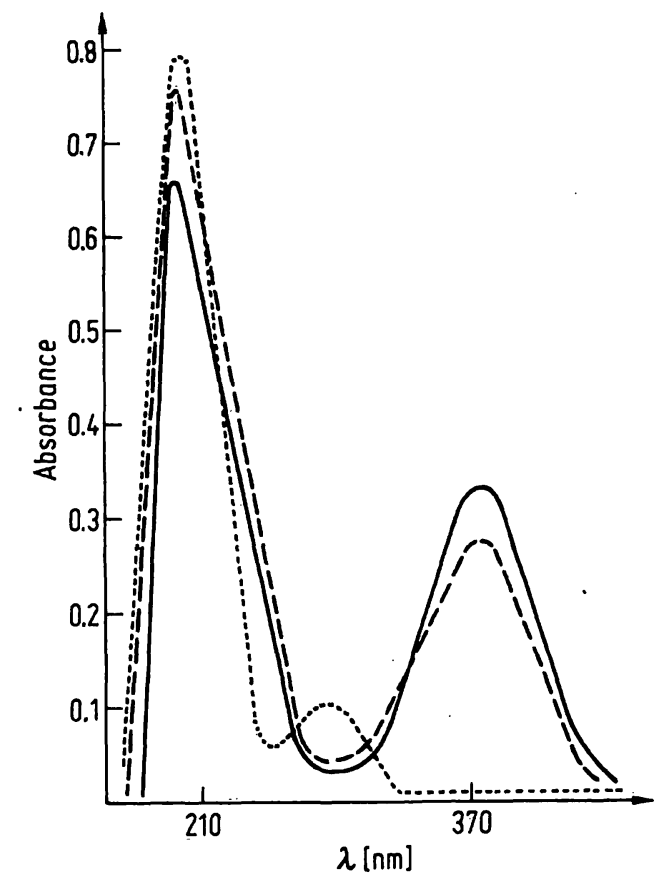

Fig. 1. Spectral changes of ambilhar upon addition of sodium metabisulphite and lead acetate.

It is clear that the peak at $370 \mathrm{~nm}$ in the drug (-) is slightly reduced after the addition of sodium metabisulphite (reducing agent) (-). However after the addition of lead acetate to this mixture (----) complete disappearance of this peak was observed. This probably indicates the formation of a soluble ambilhar lead complex.

Tab. 2. Effect of ambilhar administration on liver content of lead after injection of lead acetate for three weeks (50 mg per animal per day).

\begin{tabular}{|c|c|c|c|c|}
\hline Group of animals & $\begin{array}{l}\text { Num- } \\
\text { ber } \\
\text { of } \\
\text { ani- } \\
\text { mals }\end{array}$ & $\begin{array}{l}\text { Liver } \\
\text { lead } \\
\mathrm{mg} / \mathrm{kg} \\
\text { fr. wt. }\end{array}$ & $\begin{array}{l}\text { Urinary } \\
\text { lead } \\
\mathrm{mg} / \mathrm{l}\end{array}$ & 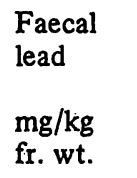 \\
\hline $\begin{array}{l}\text { Group } 4 \\
\text { dosed with lead } \\
\text { only (control) }\end{array}$ & 10 & $\begin{array}{c}12.5 \\
\pm(2.5)\end{array}$ & $\begin{array}{c}0.17 \\
\pm(0.05)\end{array}$ & $\begin{array}{c}0.04 \\
\pm(0.065)\end{array}$ \\
\hline $\begin{array}{l}\text { Group } 5 \\
\text { dosed with } \\
5 \mathrm{mg} \text { ambilhar } \\
\text { after lead }\end{array}$ & 10 & $\begin{array}{r}6.4^{* *} \\
\pm(1.25)\end{array}$ & $\begin{array}{c}1.75 * * \\
\pm(0.35)\end{array}$ & $\begin{array}{c}1.55 * * \\
\pm(0.55)\end{array}$ \\
\hline $\begin{array}{l}\text { Group } 6 \\
\text { dosed with } \\
50 \mathrm{mg} \text { ambilhar } \\
\text { after lead }\end{array}$ & 10 & $\begin{array}{r}2.2^{* *} \\
\pm(0.45)\end{array}$ & $\begin{aligned} & 2.35^{* *} \\
& \pm(0.4)\end{aligned}$ & $\begin{array}{r}1.95 * * \\
\pm(0.455)\end{array}$ \\
\hline
\end{tabular}

\pm standard deviation.
$* *$ significant at $1 \%$ level of probability

Figure 1 illustrates the ultra violet spectra of ambilhar and its lead complex. It is clear that the peak at $370 \mathrm{~nm}$ has disappeared upon the formation of the soluble ambilhar lead complex. The effect of reducing agents (sodium metabisulphite) on the complex formation was investigated by studying the absorption spectrum of the drug in the absence of lead. 
It is clear from table 1 that administration of ambilhar to guinea pigs intoxicated with lead for one week, results in a significant urinary and faecal excretion of the metal with a concomitant depletion of liver lead. At the lower dose of the drug about $80 \%$ of liver lead was eliminated and at the higher dose level about $97 \%$ of liver lead was eliminated.

It is clear from table 2 that administration of ambilhar to animals intoxicated with lead for three weeks, resulted in a significant decrease in liver lead. On the other hand a significant increase in urinary and faecal lead was observed. At a lower dose level about $50 \%$ of liver lead was eliminated and at the higher dose level of the drug about $84 \%$ of the metal in liver was eliminated.

\section{Discussion}

It is clear from table 1 that administration of ambilhar resulted in a significant decrease in the lead content of the liver. The degree of depletion of liver lead is dosedependent. At a dose level of $5 \mathrm{mg}$ per animal for 7 consecutive days, about $80 \%$ of liver lead was eliminated, while at a $50 \mathrm{mg}$ dose level nearly complete depletion of liver lead was observed.

The decrease of liver lead upon administration of the drug was accompanied by a significant increase in urinary and faecal lead excretion.

\section{References}

1. Salah, M. K., Hammady, I. M., Hamed, M. Y. \& Abdel Aziz, F. T. (1970), Zentralbl. Veterinaermed. Reihe A, 17, 257260.

2. Abdel Aziz, F. T., Al-Mallah, A. K. \& Hassanein, R. R. (1976), Zentralbl. Veterinaermed. Reihe A, 23, 475-478.
Table 2 shows the effect of ambilhar on liver lead after intoxication of the liver with the metal for a longer period (three weeks). At a dose level of $5 \mathrm{mg}$, the drug caused a $50 \%$ decrease in the level of liver lead; at a dose level of $50 \mathrm{mg}$, the decrease of liver lead was $84 \%$. A significant increase in urinary and faecal lead excretion was also found.

These data show that ambilhar has the ability to form a soluble complex with lead, which can be easily excreted. This finding is also supported by the previous observations that ambilhar can easily form a complex with iron (2) and with calcium and magnesium (3).

The ability of ambilhar to ligate and form a soluble complex with lead is further supported by our in vitro studies. The ultra violet spectrum of ambilhar was found to be changed at $370 \mathrm{~nm}$ upon addition of lead acetate in the presence of sodium metabisulphite, presumably due to the formation of drug-lead complex (fig. 1). Since the metal ligation ability of ambilhar requires the presence of a reducing agent, it could be inferred that the drug is reduced in vivo prior to its metal ligation.

Compared to other lead antidotes ambilhar appears to be less toxic, and therefore could be recommended for treatment of lead intoxication.

3. Al-Khayat, T. M. N., Abdel Aziz, F. T., Izzat, N. N. \& Salah, M. (1978), J. Clin. Chem. Clin. Biochem. 16, 11-13.

4. Hessel, D. W. (1968), Perkin-Elmer, Newsletter No. 7

Dr. T. M. N. Al-Khayat and Dr. F. T. Abdel Aziz Medical Biochem. Dept. Med. College. Mosul Univ. Mosul

Iraq 
. 